that these Outlines of the Life of Christ should be accepted as a recognized authority upon the subject in our pulpits, our theological colleges, and our public schools.

\author{
H. B. Swete.
}

\title{
ST PAUL'S KNOWLEDGE OF THE GOSPEL HISTORY.
}

Der Paulinismus und die Logia Jesu, in ihrem gegenseitigen Verhältnis untersucht von D. A. REsch. Texte und Untersuchungen, N. F. xii. (J. C. Hinrichs, Leipzig, r 904.)

THIs book is the result of infinite pains and is full of interesting suggestions. Dr Resch has for years been an independent student of the Synoptic problem, and by a careful comparison of the three Synoptists, of all the variant readings of their text found in MSS and in patristic quotations, and of the non-canonical sayings attributed to our Lord, he has come to the conclusion that St Mark's is the earliest of the three, that behind St Mark lay an earlier narrative which existed primarily in Hebrew and which was used independently by the three Evangelists, each taking from it as much as suited the primary purpose of his Gospel. This earlier narrative he calls the Logia, identifying it with the Logia of Papias, and regarding it not as a mere collection of sayings, but as a narrative Gospel including the main outline of the synoptsst story as well as much of the material peculiar to each Synoptist and even the Pericope Adulterae, and this he attempted to reconstruct both in Hebrew and Greek, and published in 1898 in his volume entitled Die Logia Jesu.

In the present volume he approaches the same question from a different side, from the study of Paulinism. The Pauline Epistles seem to him to prove that St Paul had a wide knowledge of the facts of the life of Jesus, and his teaching and language shew many points of coincidence with those of the Evangelists; and this agreement is found in all the letters, the earliest as well as the latest. Whence then had St Paul, who at first purposely abstained from oral communications with the earlier apostles, acquired this knowledge? This is the question which Dr Resch sets himself to answer here. $\mathrm{He}$ is inclined to believe that $\mathrm{St}$ Paul had seen the Lord during His earthly ministry; indeed, he hints that he was the rich young man, the ruler, whom Jesus loved, but who turned away from $\mathrm{H}_{1 m}$ 
being as yet unprepared to give up his riches. This hint is, however, not followed up. The main answer to the question is that St Paul, after his conversion, received a written copy of the Hebrew Logia, perhaps from Ananias, that he had this with him during his three years in Arabia, that his mind was thoroughly steeped in it, and that all his teaching was developed from germs to be found there. To this document he sees allusions in I Cor. $x v$ 3, 1 Tim. $v 18,2$ Tim. iv 13 . In order to prove this point he marshals his facts with great skill. First (pp. 35-154) he prints every passage from St Paul in which any coincidence with the Gospels or the Agrapha can be detected; next (pp. 155-464) follow a series of excursuses in which the chief phrases and thoughts are examined ; finally (pp. 464-639), each epistle is examined separately, and the effect of the Logia on its language and teaching drawn out; then the Pauline vocabulary and Pauline doctrine as a whole is treated in the same way; and an attempt is made to shew that while Paulinism has been dependent on the Logia, it has itself influenced, though not to the degree often assumed, the final form of our three Gospels.

Does he succeed in his main contention? Not, I think, wholly or conclusively. The array of quotations is indeed imposing at first sight ; but he has all the cleverness of a general, who makes the same soldiers pass quickly by a given point dressed in different uniforms each time, and so deceives his enemy into the belief that his force is three times its real size. Again, there can be no doubt that the author overpresses his point : he prints many passages in which he would himself admit that the coincidence was very, very precarious : he does not allow for the independent use by the two writers of the same passage of the Old Testament ; or for the effect of oral tradition; or, again, for the necessity of two writers using similar language when treating the same topic. To take but one instance, from I Timothy he quotes fifty-two points of comparison: of these, thirty leave on my mind the impression of accidental coincidence, two are due to use of the Old Testament, and only twenty suggest a possible dependence on previous material, and of these one only ( $\mathrm{v} 18$ ) suggests, and it does not require, dependence on a written document.

Yet when all deductions have been made, much of real value remains, and the book will be of permanent interest to the student of the Gospels and of the Pauline Epistles alike. To put this at its lowest estımate, the facts accumulated supply a rich illustration of St Paul's language and are often very illuminating as to his meaning: but in addition to this, there is much valuable material in the excursuses, e.g. the collection of passages bearing on Trinitarian doctrine (p. 368 ), on prayer (p. 223),

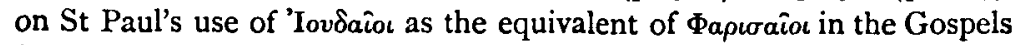
(p. 194), on the references to Jerusalem (p. 326), Gethsemane (p. 353), 


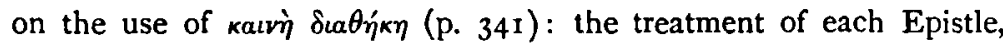
the defence of the Pauline authorship of the Pastorals, the account of Paulinism and its influence on Church history, are all well done, and in spite of the mass of his materials he makes his argument lucid and effective; nor can it be denied that he has proved that St Paul was in close touch with the traditions of the earliest Christians, that he had a real knowledge of the facts of the Lord's earthly life, and that there is a distinct possibility, nay probability, that some of the discourses and parables of the Lord lay before hım in a written form. While it seems to me purely fanciful to suggest that he was thinking of the parable of The Good Samaritan in his account of his own treatment of Onesimus, it seems more than probable that he knew the Lord's Prayer, the outline of the Sermon on the Mount, the eschatological discourse of our Lord, and that 1 Cor. vil 35 implies a knowledge of the story of Martha and Mary in the form which we have it now in St Luke's Gospel.

WALTER LOCK.

\section{THE GENUINE WRITINGS OF APOLLINARIUS.}

Apollinaris von Laodicea und seine Schule. Von Lic. Hans Lietzmann. (J. C. B. Mohr [Paul Srebeck], Tubingen. r 904.)

FRESH interest in Apollinarius was aroused some dozen years ago by the researches of Dr Draseke, who claimed (Texte u. Untersuchungen vii $3,4: 1892$ ) as the genuine work of the great heresiarch (I) the letters to Basll which the Benedictine editors of Basll's works inserted in their edition, though regarding them as forgeries; (2) the two last of the five books against Eunomius attributed to Basil, the first three of which only are believed to be his; (3) the $\ddot{\epsilon} \times \theta \epsilon \sigma \iota s \pi i \sigma \tau \epsilon \omega s$ or $\pi \epsilon \rho \dot{i}$

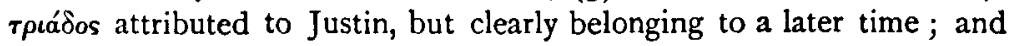
(4) the first three of the seven dialogues on the Trinity and the Incarnation, printed in the Benedictine edition of the works of Athanasius, and attributed by the MSS to Athanasius, Maximus the Confessor, or left anonymous.

Dr Dräseke thus added very largely to the scanty materials which were avalable for the study of Apollinarius, though none of these writings shews any trace of 'Apollinarian' conceptions, and he took credit for giving back to Apollınarius his own, of which he had been deprived for so many years. His arguments met with some acceptance: -as a whole, in England, by the Church Quarterly reviewer (October 